\title{
Insects as alternative feed for ruminants: comparison of protein evaluation methods
}

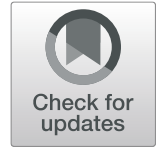

\author{
Pablo G. Toral', Gonzalo Hervás ${ }^{1}$, Mariana Gabriela González-Rosales', Alejandro G. Mendoza', \\ Lizbeth E. Robles-Jiménez ${ }^{1,2}$ and Pilar Frutos ${ }^{1 *}$ (iD
}

\begin{abstract}
Background: The high dependence of intensive ruminant production on soybean meal and the environmental impact of this crop encourage the search for alternative protein-rich feeds. The use of insects seems promising, but the extent of their ruminal protein degradation is largely unknown. This parameter has major influence not only on $\mathrm{N}$ utilization efficiency but also on the environmental burden of ruminant farming. In addition, although assessing ruminal $\mathrm{N}$ degradation represents a key first step to examine the potential of new feeds, it is a challenging task due to the lack of a reference method. This study was conducted to investigate the potential of 4 insects (Tenebrio molitor, Zophobas morio, Alphitobius diaperinus and Acheta domesticus) as alternative protein sources for ruminants, using 3 methodologies: 1) a regression technique based on the in vitro relationship between gas production and ammonia-N concentration; 2) a conventional in vitro technique of batch cultures of ruminal microorganisms, based on filtering the incubation residue through sintered glass crucibles; and 3) the in situ nylon bag technique. The in vitro intestinal digestibility of the non-degraded protein in the rumen was also determined. Soybean meal was used as a reference feedstuff.

Results: Comparison of evaluation methods (regression, in vitro and in situ) did not allow to reliably select a single value of ruminal $\mathrm{N}$ degradation for the studied substrates, but all techniques seem to establish a similar ranking, with good correlations between methods, particularly between regression and in situ results. Regardless of the methodology, nitrogen from the 4 insects (with contents ranging from 81 to $112 \mathrm{~g} / \mathrm{kg}$ of dry matter) did not show high ruminal degradation (41-76\%), this value being always lower than that of soybean meal. Furthermore, the in vitro intestinal digestibility of non-degraded $N$ was relatively high in all feeds ( $\geq 64 \%$ ).

Conclusion: Overall, these results support the potential of the 4 studied insects as alternative feedstuffs for ruminants. Among them, T. molitor showed the lowest and greatest values of ruminal $\mathrm{N}$ degradation and intestinal digestibility, respectively, which would place it as probably the best option to replace dietary soybean meal and increase the sustainability of ruminant feeding.
\end{abstract}

Keywords: In situ, In vitro, Livestock, Nitrogen degradation, Sheep

\footnotetext{
*Correspondence: p.frutos@csic.es

'Instituto de Ganadería de Montaña (CSIC-University of León), Finca

Marzanas s/n, 24346 Grulleros, León, Spain

Full list of author information is available at the end of the article
}

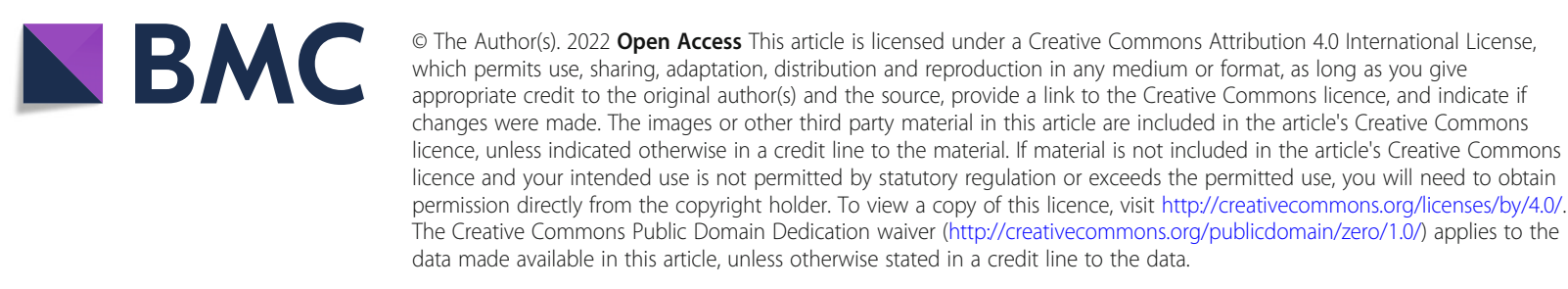




\section{Background}

Climate change has fostered research on mitigating the environmental impact of intensive ruminant farming, which has been pointed as a contributor to water eutrophication, acid deposition, and excessive nitrogen excretion [1, 2]. This environmental burden would largely be explained by the relatively low efficiency of utilization of protein-rich feeds by ruminants [3-5].

In addition, most intensive livestock production systems are highly dependent on soybean meal as the source of dietary protein. In Europe, this dependence is particularly relevant due to the ban on the use of meat meal and analogues in ruminant feeding, which encourages the search for additional protein-rich feeds [6-8].

Insects have been suggested as promising alternatives to plant proteins traditionally offered to animals [9-11]. The easy adaptation of insect production to different countries and their role in waste bioconversion and reduced land-use [9] makes them more environmentally friendly sources of dietary protein for livestock than soybean meal. However, to date there are very few scientific studies evaluating the use of insect products in ruminant diets [12-15]. Providing this information could help to push insects higher on policymaker agendas in Europe and worldwide and develop a regulatory framework for the authorization of insects as ruminant feed $[9,10]$.

Ruminal digestion largely determines the efficiency of utilization of dietary protein; knowing its degradation by rumen microbes is needed for estimation of the protein actually reaching the intestine and for prediction of protein requirements in ruminant production [5, 16, 17]. Thus, assessing the extent of protein degradation represents a first step to examine the potential of new feeds for ruminants, but available information on insect protein evaluation seems extremely scarce in the literature and it is mainly focused on silkworm (Bombyx mori) [18, 19].

Furthermore, protein evaluation of alternative feeds for ruminants is challenging: methods to estimate protein or nitrogen degradation based on in situ nylon bag incubations [16] and in vitro batch cultures of ruminal microorganisms [20] have often been questioned due to the likely overestimation caused by the loss of small particles through the pores (of either the bags or the crucibles employed in these techniques) without actually being degraded [21]. Another difficulty in measuring dietary nitrogen degradation arises from the simultaneous synthesis of ruminal microbial protein [5]. To avoid these problems, Raab et al. [17] proposed an alternative evaluation method based on linear regression between gas production and ammonia- $\mathrm{N}$ concentration in in vitro ruminal incubations. However, considering the few existing publications on this issue $[22,23]$, this proposal does not seem to have received much attention.
Thus, the value of 4 insect meals (from Tenebrio molitor, Zophobas morio, Alphitobius diaperinus, and Acheta domesticus) as protein sources for ruminant feeding was examined. To this aim, 3 different methodologies to estimate ruminal degradation were compared: 1) a regression technique based on the in vitro relationship between gas production and ammonia- $\mathrm{N}$ concentration; 2) a conventional in vitro technique of batch cultures of ruminal microorganisms, based on filtering the incubation residue through sintered glass crucibles; and 3) the in situ nylon bag technique.

\section{Methods \\ Experimental animals}

Four adult Merino ewes (body weight: $57.4 \pm 8.2 \mathrm{~kg}$ ), which were neither pregnant nor lactating, were equipped with a rumen cannula. Animals were offered a total mixed ration [dry matter (DM): $916 \mathrm{~g} / \mathrm{kg}$ of fresh matter; crude protein (CP): $205 \mathrm{~g} / \mathrm{kg}$ DM; neutral detergent fiber (NDF): $314 \mathrm{~g} / \mathrm{kg}$ DM, consisting of dehydrated alfalfa, maize and barley grain, soybean meal, vitamins and minerals, with a forage:concentrate ratio of 60:40]. The ration was offered daily at 9:00 h, at approximately 1.1 times their maintenance energy requirements [24]. Barley straw and clean drinking water were always available.

\section{Experimental substrates}

Four types of dehydrated insects were used: mealworms (Tenebrio molitor), morioworms (Zophobas morio), buffaloworms (Alphitobius diaperinus) and adult house crickets (Acheta domesticus). In addition, soybean meal was used as reference feedstuff. Tenebrio molitor was obtained from MealFood Europe (Doñinos de Salamanca, Spain) and the other three insects from Kreca Ento-Feed BV (Ermelo, the Netherlands).

The soybean meal and the insects were mixed with dry ice and then ground using an ultra-centrifugal mill (Retsch ZM 1000; Retsch Gmbh, Haan, Germany) through a 1-mm screen for in vitro incubations and through a 2-mm screen for in situ incubations. Dry ice was used to prevent the high fat content of feeds from affecting the process, embrittling the sample to achieve a homogeneous grind.

\section{Experimental procedures \\ Batch cultures of rumen microorganisms}

Batch cultures of rumen microorganisms were performed as outlined previously [25] to carry out the protein evaluation using the regression technique described by Raab et al. [17], and a conventional in vitro method.

On the 3 incubation days, ewes were given free access to the diet for $3 \mathrm{~h}$. Then, orts were removed and, $3 \mathrm{~h}$ later, samples of rumen digesta were collected through 
the cannula of each animal and filtered through 3 layers of cheesecloth. Drinking water had also been removed $1 \mathrm{~h}$ before rumen inoculum collection. Rumen fluids were immediately transferred to the laboratory in pre-warmed thermal flasks, where they were strained through a nylon membrane $(250 \mu \mathrm{m}$ of pore size; Fisher-Scientific S.L., Madrid, Spain) under a constant flow of $\mathrm{CO}_{2}$. Equal weights of the 4 strained rumen fluids were pooled and mixed (1:4) with phosphate-bicarbonate buffer solution [26]. The buffered rumen fluid $(50 \mathrm{~mL})$ was dosed in incubation flasks $(125-\mathrm{mL})$, which contained $500 \mathrm{mg}$ DM of substrate. Sealed flasks were incubated under anaerobic conditions for $16 \mathrm{~h}$ at $39.5^{\circ} \mathrm{C}$. Blanks containing buffered rumen fluid without substrate were also incubated under the same conditions. Incubations were repeated on 3 non-consecutive days (runs).

\section{Regression technique}

Following the in vitro conditions described above, each substrate was incubated in triplicate with 4 incremental levels of maize starch (Fluka 85,652, Madrid, Spain): 0, 100,200 or $300 \mathrm{mg} /$ flask. A total of 216 flasks were incubated: ( 5 incubation substrates +1 blank) $\times 4$ starch levels $\times 3$ flasks $\times 3$ incubation runs.

Head-space gas pressures were recorded at 4, 8 and $16 \mathrm{~h}$ of incubation. Accumulated gas pressure values were corrected for the amount of incubated DM and gas measured from blanks. Gas volumes were then estimated using a predictive linear regression equation derived from numerous simultaneous pressure and volume measurements [25].

After $16 \mathrm{~h}$ of incubation, the fermentation was stopped by placing the flasks into ice-water, and samples of buffered rumen fluid were centrifuged (at $976 \times g$ for $10 \mathrm{~min}$ at $\left.4{ }^{\circ} \mathrm{C}\right)$. The supernatant was acidified (1:1) with $\mathrm{HCl} 0.2 \mathrm{~mol} / \mathrm{L}$ and stored at $-30{ }^{\circ} \mathrm{C}$ until ammonia-N analysis.

Relationships between gas production and ammonia- $\mathrm{N}$ concentration were used to estimate nitrogen degradation by linear regression (reg ND), as described by Raab et al. [17], with the modifications recommended by Mota et al. [22].

\section{In vitro technique}

Incubation residues from the flasks containing $0 \mathrm{mg}$ of additional starch were filtered using pre-weighed sintered glass crucibles $(100-160 \mu \mathrm{m}$; Pyrex, UK). A total of 54 flasks were filtered: (5 incubation substrates +1 blank) $\times 3$ flasks $\times 3$ incubation runs.

Crucibles were dried in an air-forced oven $\left(103{ }^{\circ} \mathrm{C}, 24\right.$ h) and residues were analyzed for nitrogen content to estimate $\mathrm{N}$ degradation (in vitro $\mathrm{ND}$ ).

\section{In situ technique}

Ruminal nitrogen degradation was also estimated using the nylon bag technique [16]. To this aim, nylon bags $(50 \mu \mathrm{m}$ pore size; R1020, Ankom Technology Corp., Macedon, NY, USA) were filled with $6 \mathrm{~g}$ of each substrate and incubated for $16 \mathrm{~h}$ by suspending them in the rumen of each sheep (replicate) just before feeding. Five bags were incubated in each animal (1 bag/substrate) in a single day. After incubation, bags were removed, washed with cold water and stored frozen $\left(-20^{\circ} \mathrm{C},>24\right.$ h) to facilitate the detachment of ruminal microorganisms from feed particles. Once defrosted, bags were washed again with cold water in an automatic washing machine $(20 \mathrm{~min})$ and dried in a forced-air oven $\left(45^{\circ} \mathrm{C}\right.$, $48 \mathrm{~h})$. Nitrogen concentrations in the residues were analyzed to estimate $\mathrm{N}$ degradation (in situ ND).

The solubility of the DM and the $\mathrm{N}$ of each substrate was also estimated. After filling 2 bags per substrate with $6 \mathrm{~g}$ of feed, they were washed, dried and analyzed as described above for bags incubated in the rumen, with the exception that no in situ incubation was carried out.

\section{In vitro intestinal digestibility}

The in vitro intestinal digestibility of the non-degraded nitrogen (IDNDN) in the rumen was determined following the three-step in vitro procedure developed by Calsamiglia and Stern [27].

In situ incubation residues were used as the substrate for this test. From each sample, an amount equivalent to $15 \mathrm{mg}$ of $\mathrm{N}$ was weighed into polypropylene tubes. Samples were first incubated $\left(39.5^{\circ} \mathrm{C}, 1 \mathrm{~h}\right)$ with $10 \mathrm{~mL}$ of an acid solution containing $\mathrm{HCl}(0.1 \mathrm{~mol} / \mathrm{L}, \mathrm{pH}: 1.9)$ and pepsin (1 g/L; P7012, Sigma-Aldrich, Madrid, Spain) to simulate abomasal digestion. After the $\mathrm{pH}$ was neutralized (using $0.5 \mathrm{~mL}$ of $\mathrm{NaOH} 1 \mathrm{~mol} / \mathrm{L}$ ), the second incubation $\left(39.5^{\circ} \mathrm{C}, 24 \mathrm{~h}\right)$ was conducted with $13.5 \mathrm{~mL}$ of a potassium phosphate buffer solution $(0.3 \mathrm{~mol} / \mathrm{L}, \mathrm{pH}$ : 7.75) containing pancreatin (3 g/L; P7545, SigmaAldrich) to simulate intestinal digestion. Then, $3 \mathrm{~mL}$ of trichloroacetic acid was added to stop the digestion and precipitate non-degraded proteins. Samples were centrifuged $\left(10,000 \times g, 4{ }^{\circ} \mathrm{C}, 15 \mathrm{~min}\right)$ and the supernatant was stored at $-30^{\circ} \mathrm{C}$ until analyzed for soluble nitrogen content.

\section{Chemical analyses}

Samples of substrates were prepared (ISO 6498:2012) and analyzed for DM (ISO 6496:1999) and ash (ISO 5984:2002). The NDF and acid detergent fiber (ADF) contents were determined using an Ankom $^{2000}$ fiber analyzer (Ankom Technology Corp. Methods 13 and 12, respectively). The NDF was assayed with sodium sulfite and alpha-amylase, and expressed with residual ash (the latter also for $\mathrm{ADF}$ ). Ether extract (EE) was analyzed 
using the Ankom Filter Bag Technology and the technique described by AOCS [28].

Nitrogen concentration in substrates and incubation residues was analyzed (ISO 5983-2:2009) using a Kjeldahl autoanalyzer (Foss Kjeltec ${ }^{\text {Tw }}$ 2400, Hillerød, Denmark), whereas ammonia- $\mathrm{N}$ concentration in liquid incubation residues was determined by colorimetry [29].

\section{Statistical analyses}

All statistical analyses were conducted with the SAS software package (version 9.4; SAS Institute Inc., Cary, NC, USA).

The reg ND was estimated by linear regression between gas production $(x, \mathrm{~mL})$ and ammonia- $\mathrm{N}(y, \mathrm{mg})$ using the REG procedure.

Other statistical analyses were performed using the MIXED procedure. Nitrogen degradation data were analyzed by ANOVA to test the fixed effects of evaluation method (i.e., reg ND, in vitro ND and in situ ND), of incubation substrate (i.e., soybean meal, $A$. domesticus, $A$. diaperinus, T. molitor and $Z$. morio), and their interaction. In vitro IDNDN and solubility data were analyzed by ANOVA to test the fixed effects of incubation substrate. Means were separated through the pairwise differences ("pdiff") option of the least squares means ("Ismeans") statement of the MIXED procedure, and adjusted for multiple comparisons using Bonferroni's correction.

Pearson correlations between variables were examined using the CORR procedure.

Differences were declared significant at $P<0.05$ and considered a trend toward significance at $0.05 \leq P<0.10$. Least squares means are reported throughout the manuscript.

\section{Results and discussion}

\section{Chemical composition of substrates}

No statistical analysis was conducted to compare the chemical composition of substrates because each product derived from a single commercial batch.

As reported in Table 1, A. domesticus showed the greatest $\mathrm{N}$ concentration, which was close to that of $A$. diaperinus

Table 1 Chemical composition of experimental substrates, expressed in $\mathrm{g} / \mathrm{kg}$ DM (except for DM itself; $\mathrm{g} / \mathrm{kg}$ of fresh matter) $)^{\mathrm{a}}$

\begin{tabular}{lllllll}
\hline & DM & OM & N & NDF & ADF & EE \\
\hline Soybean meal & 875 & 931 & 81 & 145 & 93 & 35 \\
Tenebrio molitor & 932 & 966 & 81 & 195 & 76 & 344 \\
Zophobas morio & 937 & 966 & 60 & 96 & 53 & 488 \\
Alphitobius diaperinus & 933 & 960 & 103 & 114 & 73 & 247 \\
Acheta domesticus & 913 & 947 & 112 & 134 & 84 & 181 \\
\hline
\end{tabular}

${ }^{\mathrm{a}} D M$ dry matter; $O M$ organic matter; $N$ nitrogen; NDF neutral detergent fiber; $A D F$ acid detergent fiber; $E E$ ether extract and $21 \%$ and $46 \%$ higher than those of T. molitor and $Z$. morio, respectively, whereas soybean meal showed similar values to T. molitor. Compared with other data of $\mathrm{N}$ concentration, obtained by reverse conversion from reported $\mathrm{CP}$ contents [30-32], our results were within the very wide ranges (in $\mathrm{g} / \mathrm{kg} \mathrm{DM}$ ) for larvae of T. molitor ( $\approx 32-110$ ), $Z$. morio $(\approx 32-83$ ), and $A$. diaperinus $(\approx 96-130)$, and adults of $A$. domesticus $(\approx 16-118)$. This high variability in $\mathrm{N}$ concentration may derive from potential differences in development stage, rearing process (in particular, diet composition) and $\mathrm{N}$ determination method [30-32]. We decided to compare nitrogen instead of protein concentrations because it would prevent possible bias due to the overestimation of CP contents obtained by using the conventional nitrogen-to-protein conversion factor of 6.25 , which does not seem to apply to insect species [33-35].

Regarding other components, ether extract of $A$. diaperinus and $Z$. morio slightly exceeded previous reports $[30,31,36]$, the latter species showing 2.7 - and 14-fold greater fat content than $A$. domesticus and soybean meal, respectively. The moderate $\mathrm{EE}$ content of $A$. domesticus and the intermediate values of $T$. molitor seem consistent with mean values found in the literature [30, 31, 36].

As expected [30, 32, 37], fiber concentrations were relatively low in all substrates.

\section{Digestive utilization of nitrogen}

Nitrogen, instead of protein, degradation was used as the estimation parameter in the 3 techniques of protein evaluation to avoid, as mentioned above, a possible bias due to the as-yet unclear nitrogen-to-protein conversion factors of the 4 insect products [33-35]. It is noteworthy that the analysis actually determines the content of $\mathrm{N}$, which is then mostly transformed into protein by the conversion factor 6.25. However, in the case of insects, this factor overestimates the protein content [32] and studies based on amino acid analysis have proposed alternative conversion factors for larvae of different insect species, ranging from approximately 4.43 to $5.75[33,38,39]$.

Table 2 reports the regression equations obtained using the methodology proposed by Raab et al. [17], with

Table 2 Regression equations established between gas production $(x, \mathrm{~mL})$ and ammonia- $\mathrm{N}$ concentration $(y, \mathrm{mg})$ after $16 \mathrm{~h}$ of in vitro incubation of substrates and increasing amounts of starch

\begin{tabular}{llll}
\hline & Regression equation & Adjusted R & RMSE $^{\mathbf{a}}$ \\
\hline Soybean meal & $y=61.7-0.210 x$ & 0.893 & 1.517 \\
Tenebrio molitor & $y=35.7-0.136 x$ & 0.927 & 1.105 \\
Zophobas morio & $y=38.6-0.134 x$ & 0.933 & 0.994 \\
Alphitobius diaperinus & $y=51.7-0.092 x$ & 0.768 & 1.747 \\
Acheta domesticus & $y=55.7-0.133 x$ & 0.905 & 1.449 \\
\hline
\end{tabular}

${ }^{\mathrm{a}}$ Root mean square error 
the modifications recommended by Mota et al. [22]. Intercepts indicate a relatively high potential nitrogen degradation when gas production would be zero (between $52 \%$ and $62 \%$ for soybean meal, $A$. diaperinus and A. domesticus, and 36-38\% for T. molitor and $Z$. morio). Nevertheless, these results might be influenced by the composition of the ruminal inoculum, which was obtained from donor ewes consuming a diet very rich in CP (205 g/kg DM), and was collected 3-4 h after ingestion, which could have favored a high proteolytic activity during incubation $[5,40]$.

Estimated $\mathrm{N}$ degradation in the 5 incubation substrates, using the different methodologies, is shown in Fig. 1. Regardless the technique, lower values were found for the insects than for soybean meal $(P<0.001)$. Nitrogen degradation of this reference feed $(>85 \%)$ was higher than most available reports in the literature $[17,41,42]$, which may be explained by the high proteolytic activity of ruminal microorganisms in our conditions, and the slightly longer incubation times $(16 \mathrm{~h}$ in our case vs. $12 \mathrm{~h}$ in most available studies).

Among insects, the lowest $\mathrm{N}$ degradation was that of T. molitor $(P<0.001)$, a result that was consistently found with the 3 evaluation methods, with no differences between them (on average, $46 \% ; P>0.10$ ). Neither were statistically significant differences due to methodology detected for $A$. diaperinus and $A$. domesticus, which also showed similar degradation values between methods (on average, $72 \% ; P>0.10$ ). On the contrary, results for $Z$. morio were consistent when estimated by regression and in situ techniques $(\approx 74 \%)$, but $25 \%$ lower in the in vitro estimation $(56 \% ; P<0.001)$.
Major advantages of the in vitro technique are the high analytical capacity and low cost [5], but a greater variability in results is expected given the inherent characteristics of the method. In fact, it included an additional variation factor due to the need to scrape the crucibles to obtain the incubation residue on which $\mathrm{N}$ content is analyzed. Another concern is the potential underestimation of $\mathrm{N}$ degradation due to the increase of this compound with the growth of microorganisms (i.e., microbial protein synthesis) during incubations [43].

The regression method $[17,22]$ was proposed to avoid the confounding effect of microbial protein synthesis and, therefore, relatively higher $\mathrm{N}$ degradations would be expected. However, the illogical value of $114 \%$ degradation of soybean meal observed in our study (something that was not detected in any other case; $P<0.001$ ) would help to explain why this technique has not spread widely.

In any event, a good agreement between regression and in situ $\mathrm{N}$ degradation results was obtained for the studied insects, with no differences when comparing values obtained with one or other methods $(P>0.10$ in pairwise comparisons for each substrate). In addition, results from both techniques were highly correlated $(r=$ 0.914; $P=0.030$ ). The in situ nylon bag technique has been broadly used to examine ruminal degradation of protein-rich feedstuffs $[16,42,44]$, but it is laborintensive and difficult to standardize [5, 21]. In situ results also have the drawback related to the possible overestimation of $\mathrm{N}$ degradation due to the loss of soluble and small particles, a doubt that has also been raised for the in vitro technique and is far from recent $[5,22,45]$. In this regard, an important part of the degradation seemed to be due to solubility (see Table 3),

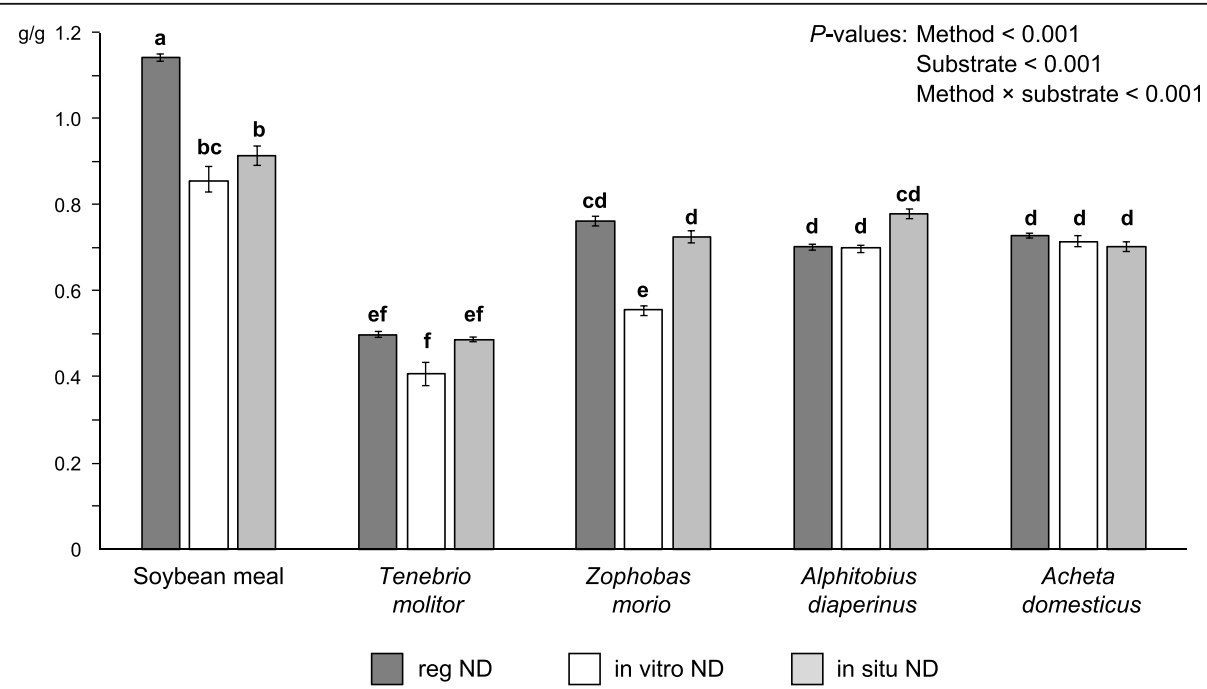

Fig. 1 Nitrogen degradation $(\mathrm{g} / \mathrm{g}$ ) of the 5 incubation substrates using 3 different methods: regression (reg ND), in vitro (in vitro ND) and in situ (in situ ND). Vertical bars represent the standard error of the mean (SEM). Different letters $(a-f)$ indicate significant differences $(P<0.05)$ for the interaction method $\times$ substrate 
Table 3 Solubility of dry matter and nitrogen of the 5 incubation substrates, $\mathrm{g} / \mathrm{g}$

\begin{tabular}{|c|c|c|c|c|c|c|c|}
\hline & \multicolumn{5}{|c|}{ Incubation substrate } & \multirow[b]{2}{*}{ SED $^{a}$} & \multirow[b]{2}{*}{$P$-value } \\
\hline & Soybean meal & Tenebrio molitor & Zophobas morio & Alphitobius diaperinus & Acheta domesticus & & \\
\hline \multicolumn{8}{|l|}{ Solubility } \\
\hline Dry matter & $0.323^{d}$ & $0.487^{c}$ & $0.713^{\mathrm{a}}$ & $0.477^{c}$ & $0.522^{b}$ & 0.006 & $<0.001$ \\
\hline Nitrogen & $0.232^{d}$ & $0.289^{c}$ & $0.535^{\mathrm{a}}$ & $0.471^{b}$ & $0.517^{\mathrm{a}}$ & 0.006 & $<0.001$ \\
\hline
\end{tabular}

a-d Within a row, different superscripts indicate significant differences $(P<0.05)$ due to the effect of the incubation substrate

${ }^{a} S E D$ standard error of the difference

which was always higher in insects than in soybean meal (for DM and N; $P<0.001$ ). Among insects, the greatest $\mathrm{N}$ solubility was found for $Z$. morio and A. domesticus, and the lowest for $T$. molitor $(P<0.001)$. This solubility accounted for $25 \%$ of in situ ND of soybean meal, approximately $60 \%$ for $T$. molitor and $A$. diaperinus, and up to $74 \%$ for $Z$. morio and A. domesticus, with no significant correlation between both parameters $(r=-$ 0.048; $P=0.939)$. In addition, although nitrogen solubility in the in situ method (Table 3) might have some analogy with the $\mathrm{N}$ degradation at zero gas production in the reg ND technique, neither was any correlation found between both results $(r=-0.173 ; P=0.781)$.

The need to find a simple, fast, cheap and accurate method for protein evaluation of feeds for ruminants, specifically to determine their ruminal degradation, has been highlighted for a long time [5, 16, 22]. However, to date there is no agreement about the most convenient technique and, possibly, there is no single method of choice, which might depend on the specific characteristics of each feedstuff or study. In this regard, although our results would not allow to reliably select a single value of ruminal $\mathrm{N}$ degradation, the 3 methods do seem to establish a similar ranking of feeds and support a relatively low ruminal $\mathrm{N}$ degradation of the 4 insects. This is consistent with the few available data about $B$. mori $[18$, 46]. Correlation analysis also supported a significant relationship between in situ and in vitro ND $(r=0.926$; $P=0.024)$ and a trend towards significance between in vitro and reg ND $(r=0.857 ; P=0.064)$.

Because dietary protein escaping ruminal degradation is an effective way to increase duodenal protein flow [5], our results would support that replacing soybean meal by the studied insects, especially $T$. molitor, might be advantageous. Nevertheless, given that part of the nondegraded $\mathrm{N}$ in the rumen would probably derive from cuticular non-digestible nitrogen [32], results from the in vitro intestinal digestibility analysis seem crucial to support the potential of insects as feed for ruminants.

In this regard, the intestinal digestibility of nondegraded protein was high for all insects (Table 4), being greatest $(P<0.001)$ for $T$. molitor $(78 \%)$, and lowest for $A$. diaperinus (64\%), which did not show differences from soybean meal $(P>0.10)$. Using a methodology similar to that of our trial, Ioselevich et al. [18] found a lower digestibility for B. mori pupae (53\%), whereas the in vivo study by Narang and Lal [47] reports an increase in apparent $\mathrm{N}$ digestibility when this latter insect replaced vegetable protein, which was associated with a trend towards greater body weight gain in calves. Compared with soybean meal, Jayanegara et al. $[12,13]$ observed a lower in vitro digestibility of DM for several insects, including T. molitor, but these authors employed the Tilley and Terry [48] technique and did not measure $\mathrm{N}$ degradation, which does not allow to discern if their results are explained by ruminal degradation (of $\mathrm{N}$ or other fractions) or subsequent digestion with pepsin. The apparent lack of other available data in the literature does not allow these inconsistent results to be attributed to insect species, methodologies or other factors.

Overall, our results support the use of insects to replace soybean meal as a source of protein in ruminant feeding. Their lower ruminal $\mathrm{N}$ degradation might contribute to improve $\mathrm{N}$ utilization efficiency and, therefore, productivity while decreasing $\mathrm{N}$ excretion to the environment. Nevertheless, further protein evaluation studies are needed due to the high heterogeneity of these feeds and the limited available information. Determination of non-protein $\mathrm{N}$ in insects and the actual utilization of this fraction by ruminants would also be recommended.

\section{Conclusions}

Comparison of evaluation methods (regression, in vitro and in situ) does not allow to reliably select a single

Table 4 In vitro intestinal digestibility of the non-degraded nitrogen in the rumen (IDNDN, g/g) of the 5 incubation substrates

\begin{tabular}{|c|c|c|c|c|c|c|c|}
\hline & \multicolumn{5}{|c|}{ Incubation substrate } & \multirow[b]{2}{*}{ SED $^{a}$} & \multirow[b]{2}{*}{$P$-value } \\
\hline & Soybean meal & Tenebrio molitor & Zophobas morio & Alphitobius diaperinus & $\overline{\text { Acheta domesticus }}$ & & \\
\hline IDNDN & $0.680^{\mathrm{bc}}$ & $0.782^{\mathrm{a}}$ & $0.703^{b}$ & $0.640^{c}$ & $0.728^{\mathrm{b}}$ & 0.018 & $<0.001$ \\
\hline
\end{tabular}

a-c Different superscripts indicate significant differences $(P<0.05)$ due to the effect of the incubation substrate

${ }^{a}$ SED Standard error of the difference 
value of ruminal $\mathrm{N}$ degradation for the studied substrates (soybean meal, $A$. domesticus, $A$. diaperinus, $T$. molitor and Z. morio), although all techniques seem to establish a similar ranking. Regardless of the methodology, nitrogen from the 4 insects (with contents ranging from 81 to $112 \mathrm{~g} / \mathrm{kg} \mathrm{DM}$ ) would not show high ruminal degradation (41-76\%), this value being always lower than that of soybean meal. Furthermore, the in vitro intestinal digestibility of non-degraded $\mathrm{N}$ in the rumen appears to be relatively high in all feeds $(\geq 64 \%)$. Overall, these results support the potential of the 4 studied insects as alternative feedstuffs for ruminants. Among them, T. molitor showed the lowest and greatest values of ruminal $\mathrm{N}$ degradation and intestinal digestibility, respectively, which would place it as probably the best option to replace dietary soybean meal and increase the sustainability of ruminant feeding.

\section{Abbreviations}

ADF: Acid detergent fiber; CP: Crude protein; DM: Dry matter; EE: Ether extract; IDNDN: Intestinal digestibility of the non-degraded nitrogen; NDF: Neutral detergent fiber; ND: Nitrogen degradation; OM: Organic matter; SED: Standard error of the difference; SEM: Standard error of the mean

\section{Acknowledgements}

This work was conducted within the framework of project PIE 202040E100 (CSIC, Spanish National Research Council). Pablo G. Toral benefited from a Ramón y Cajal research contract (RYC-2015-17230), from the Spanish Ministry of Economy and Competitiveness (MINECO), co-funded by the European Social Fund. Lizbeth E. Robles-Jiménez was granted a SEGIB-Fundación Carolina fellowship.

\section{Authors' contributions}

PGT: Conceptualization, Investigation, Formal analysis, Visualization, Validation, Writing - Original Draft; GH: Conceptualization, Investigation Formal analysis, Visualization, Validation, Writing - Review \& Editing, Project administration; MGGR: Investigation, Formal analysis, Writing - Review \& Editing; AGM: Investigation, Writing - Review \& Editing; LERJ: Writing Review \& Editing; PF: Conceptualization, Investigation, Validation, Writing Original Draft, Supervision, Funding acquisition. All authors read and approved the final manuscript.

\section{Funding}

This research did not receive any specific grant from funding agencies in the public, commercial, or not-for-profit sectors.

\section{Availability of data and materials}

The datasets from the current study are available from the corresponding author on reasonable request.

\section{Declarations}

\section{Ethics approval}

Experimental procedures with animals were conducted in accordance with European Union and Spanish legislations for the protection of animals used for experimental and other scientific purposes (Council Directive 2010/63/EU and Royal Decree 53/2013, respectively), being approved by the Research Ethics Committees of the Instituto de Ganadería de Montaña (CSIC-ULE), the Spanish National Research Council (CSIC), and the Junta de Castilla y León (Spain).

\section{Consent for publication}

Not applicable.

\section{Competing interests}

The authors declare that they have no competing interests.

\section{Author details}

Instituto de Ganadería de Montaña (CSIC-University of León), Finca Marzanas s/n, 24346 Grulleros, León, Spain. ${ }^{2}$ Facultad de Medicina Veterinaria y Zootecnia, Universidad Autónoma del Estado de México, No. 100 Instituto Literario 100, Col. Centro, 50000 Toluca, Estado de México, Mexico.

Received: 22 September 2021 Accepted: 21 December 2021

Published online: 11 February 2022

\section{References}

1. Külling DR, Menzi $H$, Kröber TF, Neftel A, Sutter $F$, Lischer $P$, et al. Emissions of ammonia, nitrous oxide and methane from different types of dairy manure during storage as affected by dietary protein content. J Agric Sci. 2001;137(2):235-50. https://doi.org/10.1017/S0021859601001186.

2. Hristov AN, Hanigan M, Cole A, Todd R, McAllister TA, Ndegwa PM, et al. Ammonia emissions from dairy farms and beef feedlots: a review. Can J Anim Sci. 2011;91(1):1-35. https://doi.org/10.4141/CJAS10034.

3. Cabrita ARJ, Dewhurst RJ, Abreu JMF, Fonseca AJM. Evaluation of the effects of synchronising the availability of $\mathrm{N}$ and energy on rumen function and production responses of dairy cows - a review. Anim Res. 2006;55(1):1-24. https://doi.org/10.1051/animres:2005045.

4. Cantalapiedra-Hijar G, Dewhurst RJ, Cheng L, Cabrita ARJ, Fonseca AJM, Nozière $P$, et al. Nitrogen isotopic fractionation as a biomarker for nitrogen use efficiency in ruminants: a meta-analysis. Animal. 2018;12(9):1827-37. https://doi.org/10.1017/\$1751731117003391.

5. Hristov AN, Bannink A, Crompton LA, Huhtanen P, Kreuzer M, McGee M, et al. Invited review: nitrogen in ruminant nutrition: a review of measurement techniques. J Dairy Sci. 2019;102(7):5811-52. https://doi.org/1 0.3168/jds.2018-15829

6. Vasta V, Nudda A, Cannas A, Lanza M, Priolo A. Alternative feed resources and their effects on the quality of meat and milk from small ruminant. Anim Feed Sci Technol. 2008;147(1-3):223-46. https://doi.org/10.1016/j.a nifeedsci.2007.09.020

7. Halmemies-Beauchet-Filleau A, Rinne M, Lamminen M, Mapato C, Ampapon T, Wanapat $M$, et al. Review: alternative and novel feeds for ruminants: nutritive value, product quality and environmental aspects. Animal. 2018; 12(s2):s295-309. https://doi.org/10.1017/S1751731118002252.

8. Lamminen M, Halmemies-Beauchet-Filleau A, Kokkonen T, Jaakkola S, Vanhatalo A. Different microalgae species as a substitutive protein feed for soya bean meal in grass silage based dairy cow diets. Anim Feed Sci Technol. 2019;247:112-26. https://doi.org/10.1016/j.anifeedsci.2018.11.005.

9. van Huis A, Van Itterbeeck J, Klunder H, Mertens E, Halloran A, Muir G, et al. Edible insects. Future prospects for food and feed security. Rome, Italy: Food and Agriculture Organization of the United Nations; 2013. [FAO Forestry Paper, vol. 171] https://www.fao.org/3/i3253e/i3253e.pdf

10. Makkar HPS, Tran G, Heuzé V, Ankers P. State-of-the-art on use of insects as animal feed. Anim Feed Sci Technol. 2014;197:1-33. https://doi.org/10.1016/ j.anifeedsci.2014.07.008.

11. DiGiacomo K, Leury BJ. Review: insect meal: a future source of protein feed for pigs? Animal. 2019;13(12):3022-30. https://doi.org/10.1017/S175173111 9001873.

12. Jayanegara A, Novandri B, Yantina N, Ridla M. Use of black soldier fly larvae (Hermetia illucens) to substitute soybean meal in ruminant diet: an in vitro rumen fermentation study. Vet World. 2017;10(12):1436-46. https://doi.org/1 0.14202/vetworld.2017.1439-1446.

13. Jayanegara A, Yantina N, Novandri B, Laconi EB, Nahrowi N, Ridla M. Evaluation of some insects as potential feed ingredients for ruminants: chemical composition, in vitro rumen fermentation and methane emissions. J Indones Trop Anim Agric. 2017;42(4):247-54. https://doi.org/10.14710/ jitaa.42.4.247-254.

14. Rashmi KM, Chandrasekharaia M, Soren NM, Prasad KS, David CG, Thirupathaiah $Y$, et al. Effect of dietary incorporation of silkworm pupae meal on in vitro rumen fermentation and digestibility. Indian J Anim Sci. 2018;88:731-5.

15. Beyzi BS. Effect of replacement of sunflower seed meal with isonitrogenous Polistes instabilis on in vitro methanogenesis and rumen fermentation. Insects Food Feed. 2020;6(5):489-98. https://doi.org/10.3920/JIFF2020.0044.

16. Ørskov ER, McDonald I. The estimation of protein degradability in the rumen from incubation measurements weighted according to rate of passage. J Agric Sci. 1979;92(2):499-503. https://doi.org/10.1017/S0021 859600063048. 
17. Raab L, Cafantaris $B$, Jilg T, Menke KH. Rumen protein degradation and biosynthesis. Br J Nutr. 1983:50(3):569-82. https://doi.org/10.1079/BJN19830128.

18. loselevich M, Steingaß $H$, Rajamurodov Z, Drochner W. Nutritive value of silkworm pupae for ruminants. In Proceedings of the 116 VDLUFA kongress, qualitätssicherung in landwirtschaftlichen produktionssystemen. Rostock: VDLUFA. 2004. p 108.

19. Sheikh IU, Banday MT, Baba IA, Adil S, Nissa SS, Zaffer B, et al. Utilization of silkworm pupae meal as an alternative source of protein in the diet of livestock and poultry: a review. J Entomol Zool. 2018;6:1010-6.

20. Williams BA. Cumulative gas production techniques for forage evaluation. In: Givens DI, Owen E, Axford RFE, Omed HM, editors. Forage evaluation in ruminant nutrition. Wallingford, UK: CABI Publishing; 2000. p. 189-213. https://doi.org/10.1079/9780851993447.0189.

21. Tamminga S, Williams BA. In vitro techniques as tools to predict nutrient supply in ruminants. In: Deaville ER, Owen E, Adesogan AT, Rymer C Huntington JA, Lawrence TL, editors. In vitro techniques for measuring nutrient supply to ruminants, vol. 22. Reading, UK: BSAS; 1998. p. 1-11. https://doi.org/10.1017/S0263967X00032201.

22. Mota M, Rodríguez R, Solanas E, Fondevila M. Evaluation of four tropical browse legumes as nitrogen sources: comparison of in vitro gas production with other methods to determine $\mathrm{N}$ degradability. Anim Feed Sci Technol. 2005;123-124:341-50. https://doi.org/10.1016/j.anifeedsci.2005.04.018.

23. Karlsson L, Hetta M, Udén P, Martinsson K. New methodology for estimating rumen protein degradation using the in vitro gas production technique. Anim Feed Sci Technol. 2009;153(3-4):193-202. https://doi.org/10.1016/j.a nifeedsci.2009.06.010.

24. INRA Alimentation des bovins, ovins et caprins. Besoins des animaux: valeur des aliments. Tables INRA 2007. Versailles, France: Editions Quae; 2007.

25. Hervás G, Frutos P, Giráldez FJ, Mora MJ, Fernández B, Mantecón AR. Effect of preservation on fermentative activity of rumen fluid inoculum for in vitro gas production techniques. Anim Feed Sci Technol. 2005;123:107-18. https://doi.org/10.1016/j.anifeedsci.2005.05.004

26. Goering HK, Van Soest PJ. Forage Fiber analyses (apparatus, reagents, procedures and some applications). Agricultural handbook no. 379. ARSUSDA: Washington, USA; 1970.

27. Calsamiglia S, Stern MD. A three-step in vitro procedure for estimating intestinal digestion of protein in ruminants. J Anim Sci. 1995;73(5):1459-65. https://doi.org/10.2527/1995.7351459x.

28. AOCS. Official methods and recommended practices of the American oil Chemist's society, fifth ed. (second printing) Urbana. Illinois, USA: AOCS; 2008.

29. Reardon J, Foreman JA, Searcy RL. New reactants for the colorimetric determination of ammonia. Clin Chim Acta. 1966;14(3):203-5. https://doi. org/10.1016/0009-8981(66)90120-3.

30. Rumpold BA, Schluter OK. Nutritional composition and safety aspects of edible insects. Mol Nutr Food Res. 2013;57(5):802-23. https://doi.org/10.1 002/mnfr.201200735.

31. Sánchez-Muros M-J, Barroso FG, Manzano-Agugliaro F. Insect meal as renewable source of food for animal feeding: a review. J Clean Prod. 2014 65:16-27. https://doi.org/10.1016/j.jclepro.2013.11.068.

32. Jonas-Levi A, Martinez J-J. The high level of protein content reported in insects for food and feed is overestimated. J Food Compos Anal. 2017;62: 184-8. https://doi.org/10.1016/j.ffca.2017.06.004.

33. Janssen $\mathrm{RH}$, Vincken JP, van den Broek LA, Fogliano V, Lakemond CM. Nitrogen-to-protein conversion factors for three edible insects: Tenebrio molitor, Alphitobius diaperinus, and Hermetia illucens. J Agric Food Chem. 2017;65(11):2275-8. https://doi.org/10.1021/acs.jafc.7b00471.

34. Belghit I, Lock E-J, Fumière $\mathrm{O}$, Lecrenier M-C, Renard P, Dieu M, et al. Species-specific discrimination of insect meals for aquafeeds by direct comparison of tandem mass spectra. Animals. 2019;9(5):222. https://doi. org/10.3390/ani9050222

35. Boulos S, Tännler A, Nyström L. Nitrogen-to-protein conversion factors for edible insects on the Swiss market: T. molitor, A. domesticus, and $L$. migratoria. Front Nutr. 2020;7:89. https://doi.org/10.3389/fnut.2020.00089.

36. Adámková A, Kouřimská L, Borkovcová M, Kulma M, Mlček J. Nutritional values of edible coleoptera (Tenebrio molitor, Zophobas morio and Alphitobius diaperinus) reared in the Czech Republic. Potravinarstvo. 2016; 10(1):663-71. https://doi.org/10.5219/609.

37. Finke MD. Complete nutrient composition of commercially raised invertebrates used as food for insectivores. Zoo Biol. 2002;21(3):269-85. https://doi.org/10.1002/zoo.10031
38. Ravi HK, Degrou A, Costil J, Trespeuch C, Chemat F, Vian MA. Effect of devitalization techniques on the lipid, protein, antioxidant, and chitin fractions of black soldier fly (Hermetia illucens) larvae. Eur Food Res Technol. 2020;246(12):2549-68. https://doi.org/10.1007/s00217-020-03596-8.

39. Smets R, Claes J, Van Der Borght M. On the nitrogen content and a robust nitrogen-to-protein conversion factor of black soldier fly larvae (Hermetia illucens). Anal Bioanal Chem. 2021;413(25):6365-77. https://doi.org/10.1007/ s00216-021-03595-y.

40. Yáñez-Ruiz DR, Bannink A, Dijkstra J, Kebreab E, Morgavi DP, O'Kiely P, et al. Design, implementation and interpretation of in vitro batch culture experiments to assess enteric methane mitigation in ruminants - a review. Anim Feed Sci Technol. 2016;216:1-18. https://doi.org/10.1016/j.anifeedsci.2 016.03.016.

41. Prestløkken E. In situ ruminal degradation and intestinal digestibility of dry matter and protein in expanded feedstuffs. Anim Feed Sci Technol. 1999; 77(1-2):1-23. https://doi.org/10.1016/S0377-8401(98)00246-6.

42. Frutos P, Hervás G, Giráldez FJ, Fernández M, Mantecón AR. Digestive utilization of quebracho-treated soya bean meals in sheep. J Agric Sci. 2000; 134(1):101-8. https://doi.org/10.1017/S0021859699007261.

43. Hvelplund T, Weisbjerg MR. In vitro techniques to replace in vivo methods for estimating amino acid supply. In: Deaville ER, Owen E, Adesogan AT, Rymer C, Huntington JA, Lawrence TL, editors. In vitro techniques for measuring nutrient supply to ruminants, vol. 22. Reading, UK: BSAS; 1998. p. 131-44. https://doi.org/10.1017/S0263967X00032419.

44. Hvelplund T, Weisbjerg MR. In situ techniques for the estimation of protein degradability and postrumen availability. In: Givens DI, Owen E, Axford RFE, Omed HM, editors. Forage evaluation in ruminant nutrition. Wallingford, UK: CABI Publishing; 2000. p. 233-58. https://doi.org/10.1079/9780851993447. 0233

45. Givens DI, Owen E, Axford RFE, Omed HM. Forage evaluation in ruminant nutrition. Wallingford, UK: CABI Publishing; 2000. https://doi.org/10.1079/ 9780851993447.0000.

46. Chandrasekharaiah M, Sampath KT, Praveen US. Chemical composition and in vitro digestibility of certain commonly used feedstuffs in ruminant rations. Indian J Dairy Sci. 2004;57:114-7.

47. Narang MP, Lal R. Evaluation of some agro-industrial wastes in the feed of Jersey calves. Agric Wastes. 1985;13(1):15-21. https://doi.org/10.1016/0141-4 607(85)90008-3.

48. Tilley JMA, Terry RA. A two-stage technique for the in vitro digestion of forage crops. Grass For Sci. 1963;18(2):104-11. https://doi.org/10.1111/j.13 65-2494.1963.tb00335.x.

\section{Ready to submit your research? Choose BMC and benefit from:}

- fast, convenient online submission

- thorough peer review by experienced researchers in your field

- rapid publication on acceptance

- support for research data, including large and complex data types

- gold Open Access which fosters wider collaboration and increased citations

- maximum visibility for your research: over 100M website views per year

At BMC, research is always in progress.

Learn more biomedcentral.com/submissions 